\title{
Accounting Researchers in Asia Pacific: A Study on Publication Productivity and Citation Analysis
}

\author{
Dr. Teck Heang Lee (Corresponding author) \\ Senior Lecturer, Department of Business Studies \\ Help University \\ E-mail: lee.teck.heang@help.edu.my \\ Dr. Ching Seng Yap \\ Assistant Professor, Graduate School of Business \\ Universiti Tun Abdul Razak \\ E-mail: chingseng@unirazak.edu.my \\ Dr. Yet Mee Lim
}

Associate Professor, Faculty of Accountancy and Management

Universiti Tunku Abdul Rahman

E-mail: limym@utar.edu.my

Dr. Cai Lian Tam

Lecturer, School of Medicine and Health Sciences

Monash University Sunway Campus

E-mail: tam.cai.lian@med.monash.edu.my

Received: February 24, 2012

Accepted: March 18, 2012

Published: June 1, 2012

doi:10.5296/ajfa.v4i1.1443

URL: http://dx.doi.org/10.5296/ajfa.v4i1.1443

\begin{abstract}
Research quality and productivity are the important dimensions that affect the employability and rewards of university faculty members. Generally, the publication achievement of university faculty members can be measured by the number of papers published in reputable journals as well as the number of citations obtained from their publications. This study examines the publication productivity of accounting faculty members of Asia Pacific universities in the top accounting journals for the period 2000 to 2010. The present study also
\end{abstract}




\section{Macrothink}

measures the publication achievement using the number of citations of the researchers' publications in these journals for the same period based on the search from Google Scholar, Scopus and Social Science Citation Index. The study found that Hun-Tong Tan is the most productive researcher in the top 18 accounting journals, followed by R. G. Walker and Michael Bradbury. When a sub-set of the top 5 accounting journals is used, the top three researchers are Hun-Tong Tan (NTU), Clive S. Lennox (HKUST) and Robert H. Chenhall (Monash U). Using the citation count, the present study found that T.J. Wong (CUHK), Robert H. Chenhall, and Ferdinand A. Gul (Monash U) obtained the highest total citations from both Google Scholar and Scopus. However, when Social Science Citation Index is used, T.J. Wong, Robert H. Chenhall, and Hun-Tong Tan are the top three. The results of this study provide the evidence of the contributions by the Asia Pacific universities' faculties towards high quality accounting research and publications over the last decade.

Keywords: Publication productivity, Citation count, Google Scholar, Scopus, Social Science Citation Index 


\section{Introduction}

"Publish or perish" is a common phrase used to describe the present situation of academic staffs' performance in institutions of higher learning (Bline, 2007). This is because faculty staff members are expected to secure research grants, to conduct research projects as well as to publish research papers to meet their research productivity assessments (Everett, Nue \& Green 2003). Research activities and publication productivity represent one of the major key performance indicators (KPIs) of the faculty members in most of the universities (Kusairi \& Fatimah, 2008).

According to Hasselback, Reinstein and Schwan (2000), various parties such as the academic administrators, faculty members and potential doctoral candidates are interested to have information about the research productivity of academics. For example, individual faculty members need such information to justify their hiring, compensation and promotion, tenure decisions, faculty awards and research grants (Pickerd, Stephens, Summers \& Wood, 2011). On the other hand, university administrators need such data to provide a fair and objective performance evaluation of their academics (Hasselback, Reinstein \& Schwan, 2003). Information on research productivity of faculty members also helps potential doctoral candidates to identify research supervisors to provide suitable and relevant mentorship (Pickerd et al., 2011).

In view of the importance of information on research productivity, extensive research on publication productivity have been conducted in various business disciplines such as accounting (Stammerjohan \& Hall, 2002; Chan, Chen, \& Cheng, 2005, Chan \& Liano, 2009; Chan, Chang, Tong, \& Zhang, 2011), finance (Chan, Chen, \& Steiner, 2004; Heck \& Cooley, 2005), information systems (Clark, Warren, \& Au, 2009), knowledge management and intellectual capital (Serenko \& Bontis, 2004), and marketing (Cheng, Chan, \& Chan, 2003; Seggie \& Griffith, 2009). A review of literature in this area shows that most of the studies conducted to examine the research productivity were carried out in the Western countries. Very few studies were done on the research productivity in Asia, despite the fact that researchers from Asian countries have been actively publishing their research findings in reputable and high impact journals. Hence, a research study that examines the research productivity of research in the Asian countries would in turn fill up such a research gap.

To make a contribution to the existing literature in research productivity, the present study aims to (1) examine the publication productivity of accounting faculty members in Asia-Pacific universities in the top accounting journals for the period 2000 to 2010; and (2) measures the publication achievement using the number of citations of the researchers' publications in these journals for the same period based on the search from Google Scholar, Scopus and Social Science Citation Index. Since the study adopts two different methods (i.e. publication and citation count) in evaluating the publication performance of the accounting faculty members in the Asia Pacific, it should provide a most up-to-date and comprehensive examination to the accounting researchers in the region. Hence, timely, reliable and convincing results could be expected from the present study. 
The structure of the latter part of this paper is as follows: Section 2 reviews past empirical studies on accounting publication productivity. Section 3 describes the productivity measures and data selection criteria for the present study. Section 4 presents the results in accordance with the research objectives set forth in the introduction section. Lastly, the paper concludes by discussing the implications and the limitation of the study.

\section{Literature Review}

Many studies have been conducted to examine the academic institutions' and faculty members' research productivity in the Western countries. Dyl and Lilly (1985) conducted a study to examine the accounting publication productivity of academic institutions based on seven high-impact accounting journals from 1978 to 1981. Their findings show that the number of publications per faculty member in accounting has been low. In addition, it is indicated that 45 percent of the articles in the selected accounting journals were accounted for by 25 institutions only. This implies a high level of concentration in publication. A later study conducted by Jones and Roberts (2005) found similar results. They examined 1,867 articles published in six highly-rated UK and six highly-rated US academic journals from 1996 to 2006. They also found that UK journals are dominated by authors from the UK and US universities and 90 percent of the US journals were published by authors from the US institutions only. The results show that very limited numbers of authors from institutions in non-English speaking countries published in the top-rated UK and US based academic journals.

Using 40 reputable accounting journals, Hasselback et al. (2003) conducted a study to examine the most prolific accounting researchers in the US. Forty eight hundred and ninety accounting faculty members graduated from the year 1968-1997 in the US were selected as the sample of the study. The study found that Philip M. J. Reckers, Chee W. Chow, William H. Beaver, Raymond J. Chambers and Wanda A. Wallace were the top five most prolific authors in 40 journals for the period 1967-2001. Not limiting to the accounting researchers in the US, Heck (2009) examined the most prolific authors in the accounting literature from 1959-2008. Heck analyzed 17,462 articles and 10,542 authors from 25 core US accounting journals and found that the top five most frequent appearing authors were Joel S. Demski, William H. Beaver, Chee W.Chow, William R. Kinney, Jr. and Thomas A. Lee. The study also ranks the authors based on the number of papers published in the top five leading accounting journals namely Accounting, Organizations and Society, Accounting Review, Journal of Accounting and Economics, Journal of Accounting Research, and Contemporary Accounting Research. The ranking of authors in these five leading accounting journals are (i) Joel S. Demski, (ii) Robert E. Verrecchia, (iii) William H. Beaver, (iv) Robert Libby and (v) William R. Kinney, Jr.

In terms of research productivity in the Asia Pacific region, the present authors found three research studies on the universities of Australia and New Zealand. They are William and Durden (1998), Chan et al., (2005), and Chan et al. (2011). William and Durden (1998) measured the publication productivity of the Accounting Department of New Zealand University for the period 1992-1997. This study provides a comprehensive evaluation by adopting different measures to assess research productivity. The research performance of the 
department was assessed based on such measures as publications in top ten accounting journals, publications in accounting journals using weighted rankings, publications in both Australian and New Zealand accounting journals, publications in unweighted accounting and non-accounting journals, and professional accounting publications. Based on this comprehensive evaluation William and Durden (1998) found that University of Auckland and Massey University performed well when they were measured by aggregate department publications in high-quality accounting journals. On the other hand, the study also found that there is a strong tendency across departments for high reliance on a few main researchers and hence when publication is measured based on a per faculty basis, larger departments in such universities as University of Auckland and Massey University tend to have a poorer performance. The study also found that Victoria University and University of Otago have published widely in professional journals, and University of Waikato has performed well for both professional and academic journals.

Based on articles published in 18 leading accounting journals and a subset of top-five accounting journals, Chan et al. (2005) measured the publication productivity of the academic institutions and their accounting faculty members in the Asia Pacific region. Their performance was measured in a two-time period, from 1991 to 1996 and from 1997 to 2002. The results show that institutions from Australia, Hong Kong and Singapore dominate the top 20 list for both time periods. During the second time period (1997-2002), institutions from Hong Kong and Singapore have gained significant improvement in the publication productivity ranking. The distribution of the publication is highly skewed--the top five, top 10 and top 20 institutions account for $32 \%, 50 \%$ and $70 \%$ of all weighted number of articles respectively. Chan et al. (2005) found that for the period of 1991- 2002, Michael Firth, R. J. Chambers, Hun-Tong Tan, Ferdinand A. Gul and Ken T. Trotman are the most productive authors in the 18 leading journals. When the top-5 journals were used to rank the productivity of the accounting authors, the top five authors are Hun-Tong Tan, Wai Fong Chua, Suil Pae, Greg B. Clinch and Margaret A. Abernethy.

The latest study in the Asia Pacific region was conducted by Chan et al. (2011). This study examined the research productivity of the institutions of higher education in Australia and New Zealand for the period 1991-2010 using 48 high-quality accounting and finance journals. The study found an upward trend in research output for both Australian and New Zealand accounting and finance departments. The top five universities were found to be University of New South Wales, University Sydney, Monash University, University of Melbourne and University of Queensland. Massey University, the highest ranked university in New Zealand, was found to rank number 8 in the study. The study also found that if a faculty member manages to publish five papers in the 48 journals, such a person would be the top 15 percent among the 1,245 Australian and New Zealand academic staff members. Finally, this study shows that highly research productive academics are able to move to different jobs. This in turn indicates that research productivity gives rise to job mobility.

\section{Productivity Measures and Data Selection Criteria}

The present study adopts the data selection criteria based on Chan et al. (2005). Eighteen top ranked accounting journals were used in the present study. Chan et al. (2005) provided the 
following justifications of adopting these journals. Firstly, these journals are ranked as the most prestigious and influential in the accounting field. Besides, these journals also obtained good quality ratings and have existed for a long period of time (e.g., The Accounting Review was established in 1926). The chosen journals cover both general scope (e.g., The Accounting Review) and specialized accounting topics (e.g., National Tax Journal). In line with chan et al (2005), of the 18 journals, a subset of top five journals was also selected for separate analyses. These top five journals are also ranked as the top accounting journals by Hasselback et al. (2003), and Brinn, Jones and Pendleburg (1996). The list of the top 18 accounting journals is presented in Table 1 . The impact factors of these journals in SSCI and Scopus as well their ranking in ABDC and ERA are provided.

Table 1. List of the Top Accounting Journals

\begin{tabular}{|l|l|c|c|c|c|}
\hline No. & Journal Title & $\begin{array}{c}\text { SSCI } \\
\text { JIF }\end{array}$ & $\begin{array}{c}\text { SCOPUS } \\
\text { SNIP }\end{array}$ & $\begin{array}{c}\text { ABDC } \\
\text { ranking }\end{array}$ & $\begin{array}{c}\text { ERA } \\
\text { ranking }\end{array}$ \\
\hline 1. & Abacus & 0.833 & 1.084 & A & A \\
\hline 2. & Accounting and Business Research & 0.638 & 1.253 & A & A \\
\hline 3. & The Accounting Review * & 2.488 & 3.599 & A* & A* \\
\hline 4. & Accounting, Organizations and Society * & 2.337 & 3.629 & A* & A* \\
\hline 5. & Auditing: A Journal of Practice and Theory & 1.021 & 1.770 & A & A \\
\hline 6. & Behavioral Research in Accounting & Not listed & Not listed & A & A \\
\hline 7. & Contemporary Accounting Research * & 1.735 & 2.008 & A* & A* \\
\hline 8. & Journal of Accounting and Economics * & 2.817 & 4.734 & A* & A* \\
\hline 9. & Journal of Accounting and Public Policy & 0.754 & 1.406 & A & A \\
\hline 10. & Journal of Accounting Literature & Not listed & Not listed & A & A \\
\hline 11. & Journal of Accounting Research $*$ & 3.346 & 3.995 & A* & A* \\
\hline 12. & Journal of Accounting, Auditing, and Finance & Not listed & 0.607 & A & A \\
\hline 13. & Journal of Management Accounting Research & Not listed & Not listed & A & A* \\
\hline 14. & Journal of the American Taxation Association & Not listed & Not listed & A & B \\
\hline 15. & Journal of Business Finance and Accounting & 0.549 & 1.107 & A & A \\
\hline 16. & National Tax Journal & 0.688 & 0.852 & A & A* \\
\hline 17. & Review of Accounting Studies & 1.972 & 1.956 & A* & A \\
\hline 18. & Review of Quantitative Finance and Accounting & Not listed & 0.702 & B & B \\
\hline
\end{tabular}

Notes.

Journals are sorted according to alphabetical order;

* denotes the top 5 journals by Chan et al. (2005) and the leading 5 journals by Heck (2009);

JIF - journal impact factor;

SNIP - source normalized impact per paper.

\section{Results}

The first research objective is to examine the publication productivity of accounting faculty members for the period 2000 to 2010. The name and the affiliation of the Asia-Pacific authors from the 18 accounting journals were collected for the period of 11 years from 2000 to 2010. Unweighted number of article is computed by counting the number of articles 
published by an author regardless the number of authors for that paper. When an article is authored by multiple researchers, the weighted number of article published per author is used to adjust for co-authorship and is measured by dividing one by the number of authors for that paper.

Based on the 18 accounting journals, Hun-Tong Tan (NTU) is the most productive author in the 18 accounting journals, followed by R. G. Walker (The U of Sydney) and Michael Bradbury (UNITEC). When a sub-set of the top five journals is used, the top three most productive authors are Hun-Tong Tan (NTU), Clive S. Lennox (HKUST) and Robert H. Chenhall (Monash U). Refer to Tables 2 and 3 for more information about the top 20 authors in terms of weighted number of articles published. 


\section{Macrothink}

Asian Journal of Finance \& Accounting

ISSN 1946-052X

2012, Vol. 4, No. 1

Table 2. The Top 20 Authors based on the 18 Accounting Journals

\begin{tabular}{|c|c|c|c|c|}
\hline Rank & Author & Affiliation & $\begin{array}{l}\text { Weighted Number } \\
\text { of Articles }\end{array}$ & $\begin{array}{l}\text { Unweighted Number } \\
\text { of Articles }\end{array}$ \\
\hline 1 & Hun-Tong Tan *\# & $\begin{array}{l}\text { Nanyang Technological University, } \\
\text { Singapore }\end{array}$ & 11.08 & 24 \\
\hline 2 & R. G. Walker \# & $\begin{array}{l}\text { University of New South Wales, } \\
\text { Australia }\end{array}$ & 7.33 & 10 \\
\hline 3 & Michael Bradbury \# & $\begin{array}{l}\text { UNITEC Institute of Technology, } \\
\text { New Zealand }\end{array}$ & 6.70 & 10 \\
\hline 4 & Ken T. Trotman *\# & $\begin{array}{l}\text { University of New South Wales, } \\
\text { Australia }\end{array}$ & 6.33 & 13 \\
\hline 5 (tied) & Clive S. Lennox *\# & $\begin{array}{l}\text { Hong Kong University of Science and } \\
\text { Technology }\end{array}$ & 5.83 & 10 \\
\hline 5 (tied) & Stewart Jones \# & University of Sydney, Australia & 5.83 & 10 \\
\hline 7 & Ferdinand A. Gul *\# & Monash University Sunway Campus & 5.50 & 13 \\
\hline 8 & Robert H. Chenhall \# & Monash University, Australia & 5.17 & 7 \\
\hline 9 & Suil Pae * & $\begin{array}{l}\text { Hong Kong University of Science and } \\
\text { Technology }\end{array}$ & 5.00 & 6 \\
\hline 10 & Guochang Zhang \# & $\begin{array}{l}\text { Hong Kong University of Science and } \\
\text { Technology }\end{array}$ & 4.83 & 7 \\
\hline 11 & Firth, Michael * & Hong Kong Polytechnic University & 4.67 & 10 \\
\hline 12 & Frank L. Clarke * & University of Sydney, Australia & 4.17 & 7 \\
\hline 13 & David Johnstone & University of Wollongong, Australia & 4.00 & 4 \\
\hline 14 & Chih-Ying Chen & Singapore Management University & 3.83 & 5 \\
\hline 15 & Robert W. Faff & $\begin{array}{l}\text { The University of Queensland, } \\
\text { Australia }\end{array}$ & 3.75 & 10 \\
\hline 16 & Steven F. Cahan & The University of Auckland & 3.50 & 10 \\
\hline 17 & Chong M. Lau & University of Western Australia & 3.33 & 7 \\
\hline 18 & Roger Simnett & University of New South Wales & 3.17 & 8 \\
\hline 19 (tied) & Terence Bu-Peow Ng & $\begin{array}{l}\text { Nanyang Technological University, } \\
\text { Singapore }\end{array}$ & 3.17 & 6 \\
\hline 19 (tied) & Wai Fong Chua * & $\begin{array}{l}\text { University of New South Wales, } \\
\text { Australia }\end{array}$ & 3.17 & 6 \\
\hline
\end{tabular}

Note. * denotes 8 authors who also appeared in the top 18 journals compiled by Chan et al. (2005) and \# denotes 9 authors who also appeared in the 25 core accounting journals compiled by Heck (2009). 
Table 3. The Top 20 Authors based on the Top 5 Accounting Journals

\begin{tabular}{|c|c|c|c|c|}
\hline Rank & Author & Affiliation & $\begin{array}{l}\text { Weighted } \\
\text { Number of } \\
\text { Articles }\end{array}$ & $\begin{array}{l}\text { Unweighted } \\
\text { Number of } \\
\text { Articles }\end{array}$ \\
\hline 1 & Hun-Tong Tan * & $\begin{array}{l}\text { Nanyang Technological University, } \\
\text { Singapore }\end{array}$ & 9.75 & 21 \\
\hline 2 & Clive S. Lennox & $\begin{array}{l}\text { Hong Kong University of Science } \\
\text { and Technology }\end{array}$ & 5.00 & 8 \\
\hline 3 & Robert H. Chenhall * & Monash University, Australia & 4.17 & 6 \\
\hline 4 & Suil Pae * & $\begin{array}{l}\text { Hong Kong University of Science } \\
\text { and Technology }\end{array}$ & 4.00 & 5 \\
\hline 5 & Ken T. Trotman * & $\begin{array}{l}\text { University of New South Wales, } \\
\text { Australia }\end{array}$ & 3.50 & 8 \\
\hline 6 & Guochang Zhang * & $\begin{array}{l}\text { Hong Kong University of Science } \\
\text { and Technology }\end{array}$ & 3.50 & 5 \\
\hline 7 & Ferdinand A. Gul * & $\begin{array}{lll}\text { Monash } & \text { University } & \text { Sunway } \\
\text { Campus } & & \\
\end{array}$ & 3.33 & 7 \\
\hline 8 & Wai Fong Chua * & $\begin{array}{l}\text { University of New South Wales, } \\
\text { Australia }\end{array}$ & 2.67 & 5 \\
\hline 9 & Chul W. Park & Sungkyunkwan University & 2.33 & 5 \\
\hline 10 & Peter F. Chen & $\begin{array}{l}\text { Hong Kong University of Science } \\
\text { and Technology }\end{array}$ & 2.00 & 4 \\
\hline 11 & $\begin{array}{ll}\text { Rachel } & \text { F. } \\
\text { Baskerville-Morley } & \\
\end{array}$ & $\begin{array}{l}\text { Victoria University of Wellington, } \\
\text { New Zealand }\end{array}$ & 2.00 & 2 \\
\hline 12 & T. J. Wong * & Chinese University of Hong Kong & 1.83 & 4 \\
\hline 13 & James R. Frederickson * & $\begin{array}{l}\text { Hong Kong University of Science } \\
\text { and Technology }\end{array}$ & 1.67 & 4 \\
\hline 14 & Jong-Hag Choi & $\begin{array}{l}\text { Hong Kong University of Science } \\
\text { and Technology }\end{array}$ & 1.58 & 5 \\
\hline 15 (tied) & Peter M. Clarkson * & $\begin{array}{l}\text { The University of Queensland, } \\
\text { Australia }\end{array}$ & 1.58 & 3 \\
\hline 15 (tied) & Terence Bu-Peow Ng & $\begin{array}{l}\text { Nanyang Technological University, } \\
\text { Singapore }\end{array}$ & 1.50 & 3 \\
\hline 17 (tied) & Anne Wyatt & $\begin{array}{l}\text { The University of Queensland, } \\
\text { Australia }\end{array}$ & 1.50 & 2 \\
\hline 17 (tied) & John Roberts & University of Sydney, Australia & 1.50 & 2 \\
\hline 17 (tied) & Zoltan P. Matolcsy & $\begin{array}{l}\text { University of Technology Sydney, } \\
\text { Australia }\end{array}$ & 1.50 & 2 \\
\hline 20 & Jeong-Bon Kim & City University of Hong Kong & 1.33 & 4 \\
\hline
\end{tabular}

Note. * denotes 10 authors who also appeared in the top 5 journal list compiled by Chan et al. (2005) 
The second research objective is to measure the publication achievement for the period 2000 to 2010 using the number of citations. The name of each author who appeared in the 18 journals was searched from three academic citation indexes - SSCI, Scopus, and Google Scholar.

Using the citation analysis method, the study found that Robert H. Chenhall (Monash U), T.J. Wong (CUHK), and Ferdinand A. Gul (Monash U) obtained the highest total citations from both Scopus and Google Scholar. However, when SSCI is used, T.J. Wong (CUHK), Robert H. Chenhall (Monash U), and Hun-Tong Tan (NTU) are the top three most productive authors. Refer to Tables 4, 5 and 6 for more information about the top 20 authors in terms of total citation.

Table 4. The Top 20 Most Cited Asia-Pacific Accounting Authors in SSCI

\begin{tabular}{|c|c|c|c|}
\hline Rank & Author & Affiliation & Total Citation \\
\hline 1 & T.J. Wong & Chinese University of Hong Kong & 225 \\
\hline 2 & Robert H. Chenhall & Monash University & 213 \\
\hline 3 & Hun-Tong Tan & Nanyang Technological University & 183 \\
\hline 4 & Joseph P. H. Fan & Chinese University of Hong Kong & 143 \\
\hline 5 & Chul W. Park & Sungkyunkwan University & 135 \\
\hline 6 & Ferdinand A. Gul & Monash University Sunway Campus & 130 \\
\hline 7 & Donald J. Stokes & University of Technology, Sydney & 122 \\
\hline 8 & Wai Fong Chua & University of New South Wales & 102 \\
\hline 9 & Easton Peter & University of Notre Dame & 100 \\
\hline 10 & Peter M. Clarkson & University of Queensland & 98 \\
\hline 11 & Andrew Ferguson & University of Technology, Sydney & 85 \\
\hline 12 & Ken T. Trotman & University of New South Wales & 82 \\
\hline 13 & Margaret A. Abernethy & University of Melbourne & 81 \\
\hline 14 & James R. Frederickson & $\begin{array}{l}\text { Hong Kong University of Science and } \\
\text { Technology }\end{array}$ & 78 \\
\hline 15 & Jere R. Francis & University of Melbourne & 76 \\
\hline 16 & Clive S. Lennox & $\begin{array}{l}\text { Hong Kong University of Science and } \\
\text { Technology }\end{array}$ & 69 \\
\hline 17 & Jeong-Bon Kim & City University of Hong Kong & 62 \\
\hline 18 & Rachel F. Baskerville & Victoria University of Wellington & 61 \\
\hline 19 (tied) & Woody Wu & Chinese University of Hong Kong & 60 \\
\hline 19 (tied) & Jong-Hag Choi & City University of Hong Kong & 60 \\
\hline
\end{tabular}




\section{Macrothink}

Asian Journal of Finance \& Accounting

ISSN 1946-052X

2012, Vol. 4, No. 1

Table 5. The Top 20 Most Cited Asia-Pacific Accounting Authors in Scopus

\begin{tabular}{|l|l|l|l|}
\hline Rank & Author & Affiliation & Total Citation \\
\hline 1 & Robert H. Chenhall & Monash University & 376 \\
\hline 2 & T.J. Wong & Chinese University of Hong Kong & 371 \\
\hline 3 & Ferdinand A. Gul & Monash University Sunway Campus & 299 \\
\hline 4 & Joseph P. H. Fan & Chinese University of Hong Kong & 245 \\
\hline 5 & Hun-Tong Tan & Nanyang Technological University & 212 \\
\hline 6 & Chul W. Park & Sungkyunkwan University & 200 \\
\hline 7 & Wai Fong Chua & University of New South Wales & 185 \\
\hline 8 & Charles J. P. Chen & City University of Hong Kong & 172 \\
\hline 9 & Donald J. Stokes & University of Technology, Sydney & 171 \\
\hline 10 & Michael Firth & Hong Kong Polytechnic University & 156 \\
\hline 11 & Jeong-Bon Kim & City University of Hong Kong & 137 \\
\hline 12 (tied) & Easton Peter & University of Notre Dame & 132 \\
\hline 12 (tied) & Margaret A. Abernethy & University of Melbourne & 132 \\
\hline 14 (tied) & James R. Frederickson & $\begin{array}{l}\text { HongKong University of Science and } \\
\text { Technology }\end{array}$ & 117 \\
\hline 14 (tied) & Andrew Ferguson & University of Technology, Sydney & 117 \\
\hline 16 (tied) & Y. T. Mak & National University of Singapore & 108 \\
\hline 16 (tied) & Jere R. Francis & University of Melbourne & 108 \\
\hline 18 & Rachel F. Baskerville & Victoria University of Wellington & 105 \\
\hline 19 & Ken T. Trotman & University of New South Wales & 100 \\
\hline 20 & Chi-Wen Jevons Lee & $\begin{array}{l}\text { Hong Kong University of Science and } \\
\text { Technology }\end{array}$ & 97 \\
\hline
\end{tabular}


Table 6. The Top 20 Most Cited Asia-Pacific Accounting Authors in Google Scholar

\begin{tabular}{|l|l|l|l|}
\hline Rank & Author & Affiliation & Total Citation \\
\hline 1 & T.J. Wong & Chinese University of Hong Kong & 1,218 \\
\hline 2 & Robert H. Chenhall & Monash University & 1,030 \\
\hline 3 & Ferdinand A. Gul & Monash University Sunway Campus & 907 \\
\hline 4 & Joseph P. H. Fan & Chinese University of Hong Kong & 875 \\
\hline 5 & Chul W. Park & Sungkyunkwan University & 652 \\
\hline 6 & Hun-Tong Tan & Nanyang Technological University & 582 \\
\hline 7 & Easton Peter & University of Notre Dame & 498 \\
\hline 8 & Wai Fong Chua & University of New South Wales & 462 \\
\hline 9 & Donald J. Stokes & University of Technology, Sydney & 420 \\
\hline 10 & Margaret A. Abernethy & University of Melbourne & 409 \\
\hline 11 & Michael Firth & Hong Kong Polytechnic University & 408 \\
\hline 12 & Charles J. P. Chen & City University of Hong Kong & 384 \\
\hline 13 & Jeong-Bon Kim & City University of Hong Kong & 367 \\
\hline 14 & Clive S. Lennox & Hong Kong University of Science and Technology & 359 \\
\hline 15 & Y. T. Mak & National University of Singapore & 323 \\
\hline 16 & Woody Wu & Chinese University of Hong Kong & 322 \\
\hline 17 & Selto Frank H & University of Melbourne & 318 \\
\hline 18 & David C. Hay & University of Auckland & 314 \\
\hline 19 (tied) & Hoque Zahirul & Griffith University & 310 \\
\hline 19 (tied) & James Wendy & Griffith University & 310 \\
\hline & & & \\
\hline
\end{tabular}

When the results of this study are compared with Heck (2009), seven of the top 10 authors in the five leading accounting journals with at least five appearances. It is noteworthy to point out that two Asia-Pacific authors, Hun-Tong Tan (NTU) and Ken. T. Trotman (UNSW), are listed as the top 100 most prolific authors in the five leading accounting journals, ranked $21^{\text {st }}$ and $51^{\text {st }}$ respectively. Nine of the top 10 authors of the 18 accounting journals compiled by the present study also appear in the list of 25 core accounting journals compiled by Heck (2009). (refer to note in table 2)

As this study adopts the data selection criteria from Chan et al. (2005), it will be meaningful to compare the results of these two studies over two periods of time. Based on the weighted number of articles, of the top 20 authors in the 18 journals and the top 5 journals in Chan et al.'s study, eight and ten authors respectively remain in the list of this study, meaning that the current list contain about 50\% new authors. (refer to note in table 2 \& 3)

In terms of the most cited articles authored by the Asia-Pacific researchers, "the management control system design within its organizational context: findings from contingency-based research and directions for the future" by Robert H. Chenhall (Monash U), and "corporate ownership structure and the informativeness and accounting earnings in East Asia” by Joseph P. H. Fan and T. J. Wong (both CUHK) are consistently ranked as the top 2 articles with highest citations in all three academic citation indexes of SSCI, Scopus, and Google Scholar. Refer to Tables 7, 8 and 9 for the most cited 20 articles in the three indexes respectively. 
Table 7. The Top 20 Most Cited Articles in SSCI

\begin{tabular}{|c|c|c|}
\hline Rank & Author, Article Title, Journal Title & Total Cited \\
\hline 1 & $\begin{array}{l}\text { Chenhall, R. H. (2003). Management control systems design within its } \\
\text { organizational context: Findings from contingency-based research and } \\
\text { directions for the future. Accounting, Organizations and Society. }\end{array}$ & 119 \\
\hline 2 & $\begin{array}{l}\text { Fan, J. P. H., \& Wong, T. J. (2002). Corporate ownership structure and the } \\
\text { informativeness of accounting earnings in East Asia. Journal of Accounting } \\
\text { and Economics. }\end{array}$ & 108 \\
\hline 3 & $\begin{array}{l}\text { Easton, P. D. (2004). PE ratios, PEG ratios, and estimating the implied } \\
\text { expected rate of return on equity capital. The Accounting Review. }\end{array}$ & 66 \\
\hline 4 & $\begin{array}{l}\text { Chenhall, R. H. (2005). Integrative strategic performance measurement } \\
\text { systems, strategic alignment of manufacturing, learning and strategic } \\
\text { outcomes: An exploratory study. Accounting, Organizations and Society. }\end{array}$ & 59 \\
\hline 5 (tied) & $\begin{array}{l}\text { Baskerville, R. F. (2003). Hofstede never studied culture. Accounting, } \\
\text { Organizations and Society. }\end{array}$ & 54 \\
\hline 5 (tied) & $\begin{array}{l}\text { Clarkson, P. M., Emby, C., \& Watt, V. M. S. (2002). Debiasing the outcome } \\
\text { effect: The role of instructions in an audit litigation setting. Auditing: A } \\
\text { Journal of Practice \& Theory. }\end{array}$ & 54 \\
\hline 7 (tied) & $\begin{array}{l}\text { Briers, M., \& Chua, W. F. (2001). The role of actor-networks and boundary } \\
\text { objects in management accounting change: A field study of an implementation } \\
\text { of activity-based costing. Accounting, Organizations and Society. }\end{array}$ & 48 \\
\hline 7 (tied) & $\begin{array}{l}\text { Ferguson, A., Francis, J. R., \& Stokes, D. J. (2003). The effects of firm-wide } \\
\text { and office-level industry expertise on audit pricing. The Accounting Review. }\end{array}$ & 48 \\
\hline 9 & $\begin{array}{l}\text { Matsunaga, S. R., \& Park, C. W. (2001). The effect of missing a quarterly } \\
\text { earnings benchmark on the CEO's annual bonus. The Accounting Review. }\end{array}$ & 46 \\
\hline 10 & $\begin{array}{l}\text { Bartov, E., Gul, F. A., \& Tsui, J. S. L. (2000). Discretionary-accruals models } \\
\text { and audit qualifications. Journal of Accounting and Economics. }\end{array}$ & 45 \\
\hline 11 (tied) & $\begin{array}{l}\text { DeFond, M. L., \& Francis, J. R. (2005). Audit research after Sarbanes-Oxley. } \\
\text { Auditing: A Journal of Practice \& Theory. }\end{array}$ & 41 \\
\hline 11 (tied) & $\begin{array}{l}\text { DeFond, M. L., \& Park, C. W. (2001). The reversal of abnormal accruals and } \\
\text { the market valuation of earnings surprises. The Accounting Review. }\end{array}$ & 41 \\
\hline 13 & $\begin{array}{l}\text { How, I.-M., Hu, B., Hwang, L.-S., \& Wu, W. (2004). Ultimate ownership, } \\
\text { income management, and legal and extra-legal institutions. Journal of } \\
\text { Accounting Research. }\end{array}$ & 40 \\
\hline 14 (tied) & $\begin{array}{l}\text { Chen, K. C. W., \& Yuan, H. (2004). Earnings management and capital } \\
\text { resource allocation: Evidence from China's accounting-based regulation of } \\
\text { rights issues. The Accounting Review. }\end{array}$ & 38 \\
\hline 14 (tied) & $\begin{array}{l}\text { Ng, T. B. P., \& Tan, H. T. (2003). Effects of authoritative guidance } \\
\text { availability and audit committee effectiveness on auditors' judgments in an } \\
\text { auditor-client negotiation context. The Accounting Review. }\end{array}$ & 38 \\
\hline 16 (tied) & $\begin{array}{l}\text { Hay, D. C., Knechel, W. R., \& Wong, N. (2006). Audit fees: A meta-analysis } \\
\text { of the effect of supply and demand attributes. Contemparary Accounting }\end{array}$ & 37 \\
\hline
\end{tabular}




\begin{tabular}{|l|l|l|}
\hline 16 (tied) & $\begin{array}{l}\text { Research. } \\
\text { fee dependence. Journal of Accounting and Economics. }\end{array}$ & 37 \\
\hline 18 & $\begin{array}{l}\text { Moores, K., \& Yuen, S. (2001). Management accounting systems and } \\
\text { organizational configuration: A life-cycle perspective. Accounting, } \\
\text { Organizations and Society. }\end{array}$ & 36 \\
\hline 19 (tied) & $\begin{array}{l}\text { Fan, J. P. H., \& Wong, T. J. (2005). Do external auditors perform a corporate } \\
\text { governance role in emerging markets? Evidence from East Asia. Journal of } \\
\text { Accounting Research. }\end{array}$ & 35 \\
\hline 19 (tied) & $\begin{array}{l}\text { Frederickson, J. R., \& Miller, J. S. (2004). The effects of proforma earnings } \\
\text { disclosures on analysts' and nonprofessional investors' equity valuation } \\
\text { judgments. The Accounting Review. }\end{array}$ & 35 \\
\hline
\end{tabular}

Table 8. The Top 20 Most Cited Articles Scopus

\begin{tabular}{|c|c|c|}
\hline Rank & Author, Article Title, Journal Title & Total Cited \\
\hline 1 & $\begin{array}{l}\text { Chenhall, R. H. (2003). Management control systems design within its } \\
\text { organizational context: Findings from contingency-based research and directions } \\
\text { for the future. Accounting, Organizations and Society. }\end{array}$ & 228 \\
\hline 2 & $\begin{array}{l}\text { Fan, J. P. H., \& Wong, T. J. (2002). Corporate ownership structure and the } \\
\text { informativeness of accounting earnings in East Asia. Journal of Accounting and } \\
\text { Economics. }\end{array}$ & 189 \\
\hline 3 & $\begin{array}{l}\text { Bartov, E., Gul, F. A., \& Tsui, J. S. L. (2000). Discretionary-accruals models } \\
\text { and audit qualifications. Journal of Accounting and Economics. }\end{array}$ & 109 \\
\hline 4 & $\begin{array}{l}\text { Eng, L. L., \& Mak, Y. T. (2003). Corporate governance and voluntary } \\
\text { disclosure. Journal of Accounting and Public Policy. }\end{array}$ & 108 \\
\hline 5 & $\begin{array}{l}\text { Chenhall, R. H. (2005). Integrative strategic performance measurement systems, } \\
\text { strategic alignment of manufacturing, learning and strategic outcomes: An } \\
\text { exploratory study. Accounting, Organizations and Society. }\end{array}$ & 104 \\
\hline 6 & $\begin{array}{l}\text { Baskerville, R. F. (2003). Hofstede never studied culture. Accounting, } \\
\text { Organizations and Society. }\end{array}$ & 92 \\
\hline 7 & $\begin{array}{l}\text { Briers, M., \& Chua, W. F. (2001). The role of actor-networks and boundary } \\
\text { objects in management accounting change: A field study of an implementation } \\
\text { of activity-based costing. Accounting, Organizations and Society. }\end{array}$ & 87 \\
\hline 8 & $\begin{array}{l}\text { Easton, P. D. (2004). PE ratios, PEG ratios, and estimating the implied expected } \\
\text { rate of return on equity capital. The Accounting Review. }\end{array}$ & 85 \\
\hline 9 & $\begin{array}{l}\text { Chen, C. J. P., \& Jaggi. B. (2000). Association between independent } \\
\text { non-executive directors, family control and financial disclosures in Hong Kong. } \\
\text { Journal of Accounting and Public Policy. }\end{array}$ & 80 \\
\hline 10 & Aharony, J., Lee, C. W. J., \& Wong, T. J. (2000). Financial packaging of IPO & 77 \\
\hline
\end{tabular}




\begin{tabular}{|c|c|c|}
\hline & firms in China. Journal of Accounting Research. & \\
\hline 11 & $\begin{array}{l}\text { Ferguson, A., Francis, J. R., \& Stokes, D. J. (2003). The effects of firm-wide and } \\
\text { office-level industry expertise on audit pricing. The Accounting Review. }\end{array}$ & 70 \\
\hline 12 & $\begin{array}{l}\text { DeFond, M. L., Francis, J. R., \& Wong, T. J. (2000). Auditor industry } \\
\text { specialization and market segmentation: Evidence from Hong Kong. Auditing: A } \\
\text { Journal of Practice \& Theory. }\end{array}$ & 68 \\
\hline 13 & $\begin{array}{l}\text { How, I.-M., Hu, B., Hwang, L.-S., \& Wu, W. (2004). Ultimate ownership, } \\
\text { income management, and legal and extra-legal institutions. Journal of } \\
\text { Accounting Research. }\end{array}$ & 64 \\
\hline 14 & $\begin{array}{l}\text { Moores, K., \& Yuen, S. (2001). Management accounting systems and } \\
\text { organizational configuration: A life-cycle perspective. Accounting, } \\
\text { Organizations and Society. }\end{array}$ & 60 \\
\hline 15 & $\begin{array}{l}\text { Hay, D. C., Knechel, W. R., \& Wong, N. (2006). Audit fees: A meta-analysis of } \\
\text { the effect of supply and demand attributes. Contemparary Accounting Research. }\end{array}$ & 59 \\
\hline $\begin{array}{l}16 \\
\text { (tied) }\end{array}$ & $\begin{array}{l}\text { Chen, K. C. W., \& Yuan, H. (2004). Earnings management and capital resource } \\
\text { allocation: Evidence from China's accounting-based regulation of rights issues. } \\
\text { The Accounting Review. }\end{array}$ & 58 \\
\hline $\begin{array}{l}16 \\
\text { (tied) }\end{array}$ & $\begin{array}{l}\text { Debreceny, R., Gray, G. L., \& Rahman, A. (2002). The determinants of Internet } \\
\text { financial reporting. Journal of Accounting and Public Policy. }\end{array}$ & 58 \\
\hline $\begin{array}{l}18 \\
\text { (tied) }\end{array}$ & $\begin{array}{l}\text { Baxter, J., \& Chua, W. F. (2003). Alternative management accounting } \\
\text { research-whence and whither. Accounting, Organizations and Society. }\end{array}$ & 57 \\
\hline $\begin{array}{l}18 \\
\text { (tied) }\end{array}$ & $\begin{array}{l}\text { Bouwens, J., \& Abernethy, M. A. (2000). The consequences of customization on } \\
\text { management accounting system design. Accounting, Organizations and Society. }\end{array}$ & 57 \\
\hline 20 & $\begin{array}{l}\text { Fan, J. P. H., \& Wong, T. J. (2005). Do external auditors perform a corporate } \\
\text { governance role in emerging markets? Evidence from East Asia. Journal of } \\
\text { Accounting Research. }\end{array}$ & 56 \\
\hline
\end{tabular}

Table 9. The Top 20 Most Cited Articles in Google Scholar

\begin{tabular}{|l|l|l|}
\hline Rank & Author, Article Title, Journal Title & Total Cited \\
\hline 1 & $\begin{array}{l}\text { Chenhall, R. H. (2003). Management control systems design within its } \\
\text { organizational context: Findings from contingency-based research and } \\
\text { directions for the future. Accounting, Organizations and Society. }\end{array}$ & 657 \\
\hline 2 & $\begin{array}{l}\text { Fan, J. P. H., \& Wong, T. J. (2002). Corporate ownership structure and the } \\
\text { informativeness of accounting earnings in East Asia. Journal of Accounting and } \\
\text { Economics. }\end{array}$ & 629 \\
\hline 4 & $\begin{array}{l}\text { Bartov, E., Gul, F. A., \& Tsui, J. S. L. (2000). Discretionary-accruals models } \\
\text { and audit qualifications. Journal of Accounting and Economics. }\end{array}$ & 391 \\
\hline 5 & $\begin{array}{l}\text { Easton, P. D. (2004). PE ratios, PEG ratios, and estimating the implied expected } \\
\text { rate of return on equity capital. The Accounting Review. }\end{array}$ & 325 \\
\hline & $\begin{array}{l}\text { Eng, L. L., \& Mak, Y. T. (2003). Corporate governance and voluntary } \\
\text { disclosure. Journal of Accounting and Public Policy. }\end{array}$ & 323 \\
\hline
\end{tabular}




\begin{tabular}{|c|c|c|}
\hline 6 & $\begin{array}{l}\text { Malina, M. A., \& Selto, F. H. (2001). Communicating and controlling strategy: } \\
\text { An empirical Study of the effectiveness of the Balanced Scorecard. Journal of } \\
\text { Management Accounting Research. }\end{array}$ & 318 \\
\hline 7 & $\begin{array}{l}\text { Hoque, Z., \& James, W. (2000). Linking Balanced Scorecard measures to size } \\
\text { and market factors: Impact on organizational performance. Journal of } \\
\text { Management Accounting Research. }\end{array}$ & 310 \\
\hline 8 & $\begin{array}{l}\text { Aharony, J., Lee, C. W. J., \& Wong, T. J. (2000). Financial packaging of IPO } \\
\text { firms in China. Journal of Accounting Research. }\end{array}$ & 256 \\
\hline 9 & $\begin{array}{l}\text { Fan, J. P. H., \& Wong, T. J. (2005). Do external auditors perform a corporate } \\
\text { governance role in emerging markets? Evidence from East Asia. Journal of } \\
\text { Accounting Research. }\end{array}$ & 246 \\
\hline 10 & $\begin{array}{l}\text { Chen, C. J. P., \& Jaggi. B. (2000). Association between independent } \\
\text { non-executive directors, family control and financial disclosures in Hong Kong. } \\
\text { Journal of Accounting and Public Policy. }\end{array}$ & 229 \\
\hline 11 & $\begin{array}{l}\text { How, I.-M., Hu, B., Hwang, L.-S., \& Wu, W. (2004). Ultimate ownership, } \\
\text { income management, and legal and extra-legal institutions. Journal of } \\
\text { Accounting Research. }\end{array}$ & 216 \\
\hline 12 & $\begin{array}{l}\text { Chenhall, R. H. (2005). Integrative strategic performance measurement systems, } \\
\text { strategic alignment of manufacturing, learning and strategic outcomes: An } \\
\text { exploratory study. Accounting, Organizations and Society. }\end{array}$ & 215 \\
\hline 13 & $\begin{array}{l}\text { Chen, K. C. W., \& Yuan, H. (2004). Earnings management and capital resource } \\
\text { allocation: Evidence from China's accounting-based regulation of rights issues. } \\
\text { The Accounting Review. }\end{array}$ & 212 \\
\hline 14 & $\begin{array}{l}\text { Baskerville, R. F. (2003). Hofstede never studied culture. Accounting, } \\
\text { Organizations and Society. }\end{array}$ & 208 \\
\hline 15 & $\begin{array}{l}\text { Hay, D. C., Knechel, W. R., \& Wong, N. (2006). Audit fees: A meta-analysis of } \\
\text { the effect of supply and demand attributes. Contemporary Accounting Research. }\end{array}$ & 206 \\
\hline 16 & $\begin{array}{l}\text { DeFond, M. L., \& Park, C. W. (2001). The reversal of abnormal accruals and } \\
\text { the market valuation of earnings surprises. The Accounting Review. }\end{array}$ & 202 \\
\hline 17 & $\begin{array}{l}\text { Briers, M., \& Chua, W. F. (2001). The role of actor-networks and boundary } \\
\text { objects in management accounting change: A field study of an implementation } \\
\text { of activity-based costing. Accounting, Organizations and Society. }\end{array}$ & 184 \\
\hline 18 & $\begin{array}{l}\text { Matsunaga, S. R., \& Park, C. W. (2001). The effect of missing a quarterly } \\
\text { earnings benchmark on the CEO's annual bonus. The Accounting Review. }\end{array}$ & 169 \\
\hline 19 & $\begin{array}{l}\text { Ali, A., Chen, T.-Y., \& Radhakrishnan, S. (2007). Corporate disclosures by } \\
\text { family firms. Journal of Accounting and Economics. }\end{array}$ & 168 \\
\hline 20 & $\begin{array}{l}\text { Bainess, A., \& Langfield-Smith, K. (2003). Antecedents to management } \\
\text { accounting change: A structural equation approach. Accounting, Organizations } \\
\text { and Society. }\end{array}$ & 161 \\
\hline
\end{tabular}




\section{Concluding Remarks}

Based on 18 accounting journals, this study examined the accounting publication productivity of Asia-Pacific authors for an eleven-year period from 2000 to 2010 using both count method and citation analysis. The most productive authors have been consistently represented using both methods as well as across three prestigious academic databases - SSCI, Scopus, and Google Scholar. When the results of this study are compared with those of Heck (2009), a substantial gap between Asia-Pacific authors and the USA and the European authors was revealed. Specifically, only two authors from the Asia-Pacific region appeared in the list of the top 100 accounting researchers in the world. This finding implies that the accounting researchers from the Asia-Pacific region have a great challenge ahead in order to be on par if not better than authors from the other parts of the world.

This study suffered from several limitations. First, the comparison made in this study with other relevant studies (e.g., Heck, 2009) may not be valid as different studies selected different number and list of journals. Second, even though the study used count method and citation analysis, the emerging methods, for examples, h-index (simultaneously measure quality and quantity of research output), and g-index (similar to h-index but places more weight to highly cited articles), were not utilized in this study. As different techniques may generate different results, the findings of this study will be interpreted within the scope of the selected journals and the techniques employed. Nevertheless, the study has attempted to analyze research productivity using three widely used academic citation indexes, SSCI, Scopus and Google Scholar, which is relatively new among the research productivity studies

It is recommended that future researchers compare productivity results using multiple methods to identify similarities and differences. Besides, online accounting journals which are publicly available under the Directory of Open Access Journals (DOAJ) and Accounting Research Network (ARN) under the Social Science Research Network (SSRN) may be selected as they are freely downloadable by researchers and thus attract a larger readership among researchers. Harzing's Publish or Perish online tool can be utilized for data collection based on Google Scholar index.

\section{References}

Bline, D.M. (2007). A Commentary on 'Publish or Perish: Is this Really a Viable Set of Options?' Accounting Education: An International Journal, 16(3), pp. 241-244. http://dx.doi.org/10.1080/09639280701430041

Brinn, T., Jones, M. J., \& Pendleburg, M. (1996). UK accounts' perception of research journal quality. Accounting and Business Research, 26(3), 265-278. http://dx.doi.org/10.1080/00014788.1996.9729516

Chan, K.C., Chang, C.C., Tong, J.Y., \& Tong, F.Z. (2011). An analysis of the accounting and finance research productivity in Australia and New Zealand in 1991-2010. Accounting and Finance, in press. 
Chan, K. C., Chen, C. R., \& Cheng, L. T. W. (2005). Ranking research productivity in accounting for Asia-Pacific Universities. Review of Quantitative Finance and Accounting, 24, 47-64. http://dx.doi.org/10.1007/s11156-005-5326-5

Chan, K. C., Chen, C. R., \& Steiner, T. L., (2004). Who is publishing? An analysis of finance research productivity in the European region. Journal of Business Finance \& Accounting, 31, 401-437. http://dx.doi.org/10.1111/j.0306-686X.2004.00545.x

Chan, K.C., \& Liano, K. (2009). Threshold citation analysis of influential articles, journals, institutions and researchers in accounting. Accounting and Finance, 49, 59-74. http://dx.doi.org/10.1111/j.1467-629X.2007.00254.x

Cheng, L. T. W, Chan, K. C., \& Chan, R. Y. K., (2003). Publication in major marketing journals. Journal of Marketing Education, 25, 163-176. http://dx.doi.org/10.1177/0273475303254023

Clark, J. G., Warren, J., \& Au, Y. A. (2009). Assessing researcher publication productivity in the leading information systems journal: A 2003-2007 update. Communications of the Association for Information Systems, 24, 225-254.

Dyl, E. A., \& Lilly, M. S. (1985). A note on institutional contributions to the accounting literature. Accounting, Organization and Society, 10, 171-175. http://dx.doi.org/10.1016/0361-3682(85)90014-5

Everett, J. Nue, D., \& Green, D.L. (2003). Commentary research productivity measurement and field of academic accounting. Canadian Accounting Perspectives, 2(2), 153-175. http://dx.doi.org/10.1506/C3GW-M2BU-NR2H-7QRR

Jones, M.J. \& Roberts, R. (2005). International publishing patterns: An investigation of leading UK and US accounting and finance journals. Journal of Business Finance \& Accounting, 32(5), 1107-1140. http://dx.doi.org/10.1111/j.0306-686X.2005.00624.x

Kusairi M. N. \& Fatimah, M.A. (2008). Some reflection on the key performance index, working

http://www.econ.upm.edu.my/ fatimah/KMN-FMA-3SocScEvaluation18Dec08.pdf

paper.

Hasselback, J.R., Reinstein, A., \& Schwan, E.S. (2000). Benchmarks for evaluating research productivity of accounting faculty. Journal of Accounting Education, 18, 79-97. http://dx.doi.org/10.1016/S0748-5751(00)00009-9

Hasselback, J.R., Reinstein, A., \& Schwan, E.S. (2003). Prolific authors of accounting literature. Advances in Accounting, 20, 95-125. http://dx.doi.org/10.1016/S0882-6110(03)20005-5

Heck, J. L. (2009). Most prolific authors in the accounting literature over the past half-century: 1959-2008. Working paper.

Heck, J. L., \& Cooley. P. L. (2005). Prolific authors in the finance literature: A half century of contributions. Journal of Finance Literature, Winter, 40-62. 


\section{Macrothink}

Asian Journal of Finance \& Accounting

ISSN 1946-052X 2012, Vol. 4, No. 1

Pickerd, J., Stephens, N.M., Summers, S.L., \& Wood, D.A. (2011). Individual accounting faculty research ranking by topical area and methodology. Issues in Accounting Education, 6(3), 471-505. http://dx.doi.org/10.2308/iace-50002

Stammerjohan, W. W., \& Hall, S. C., (2002). Evaluation of doctoral programs in accounting: An examination of placement. Journal of Accounting Education, 20, 1-27. http://dx.doi.org/10.1016/S0748-5751(01)00024-0

Seggie, S. H., \& Griffith, D. A. (2009). What does it take to get promoted in marketing academia? Understanding exceptional publication productivity in the leading marketing journals. Journal of Marketing, 73, 122-132. http://dx.doi.org/10.1509/jmkg.73.1.122

Serenko, A. \& Bontis, N. (2004). Meta-review of knowledge management and intellectual capital literature: Citation impact and research productivity ranking. Knowledge and Process Management, 11, 185-198. http://dx.doi.org/10.1002/kpm.203

Wilkinson, B. R. \& Durden, C. H. (1998). A Study of Accounting Faculty Publishing Productivity in New Zealand. Pacific Accounting Review, 10, 75-95. 